\title{
沖縄県渡嘉敷村における歯科巡回診療
}

\author{
川島伸 之占平野滋 三2) 森上誠 ${ }^{3)}$ 山口佳子4) \\ 村上真 帆 ${ }^{5)}$ 植松 宏 ${ }^{2)}$ 須田英 明 ${ }^{1)}$ 田上順 次 ${ }^{3)}$ \\ 1)東京医科㐘科大学歯学部歯科保存学第三講座（主任：須田英明教授） \\ ${ }^{2)}$ 東京医科柬科大学歯学部高齢者歯科学講座（主任：植松 宏教授） \\ 3) 東京医科歯科大学歯学部歯科保存学第一講座（主任：田上順次教授） \\ 4) 東京医科歯科大学歯学部附属病院 \\ 5) スギヤマ歯科
}

(1999 年 8 月 3 日受付)

\section{Dental Treatment and Oral Health Care on Tokashiki Island, Okinawa}

\author{
Nobuyuki Kawashima ${ }^{1)}$, Shigezo Hirano ${ }^{2)}$, Makoto Morigami ${ }^{3)}$, Yoshiko Yamaguchi ${ }^{4}$, \\ Maho Murakami ${ }^{5}$, Hiroshi Uematsu's), Hideaki Suda ${ }^{1)}$ and Junji Tagami ${ }^{3)}$ \\ 1) Department of Endodontics, Faculty of Dentistry, Tokyo Medical and Dental University \\ (Chief : Prof. Hideaki Suda) \\ 2) Department of Geriatric Dentistry, Faculty of Dentistry, Tokyo Medical and Dental University \\ (Chief : Prof. Hiroshi Uematsu) \\ ${ }^{3)}$ Department of Operative Dentistry, Faculty of Dentistry, Tokyo Medical and Dental University \\ (Chief : Prof. Junji Tagami) \\ 4) Dental Hospital of Tokyo Medical and Dental University \\ 5) Sugiyama Dental Clinic
}

\begin{abstract}
Okinawa Prefecture has been promoting dental treatment and oral health care in places where there are no dentists. The Ministry of Health and Welfare has been cooperating with eight dental colleges, including Tokyo Medical and Dental University, for promotion thereof since 1961. The 155th promotion was held on Tokashiki Island.

The caries prevalence rate of the students on Tokashiki Island was relatively high compared with the average caries prevalence rate of the same age group throughout Japan, and most of the caries were thought to be due to too many soft drinks. Resin filling was the most popular treatment during this promotion. Severe periodontal disease was observed in middle-aged persons, but we could only perform initial periodontal treatment because of the limited treatment period. Complete or partial dentures were made or repaired for many elderly. The questionnaire study showed most of the denture wearers on Tokashiki Island were satisfied with their dentures, although many dentures did not fit, and the prescription was improved.

The period of this promotion was too short to perform complete dental treatment and to prevent caries and periodontal disease, and primary prevention and higher dental hygiene education should be strengthened in no dentist areas like Tokashiki Island.
\end{abstract}

\section{I . 緒}

沖縄県に抢いては，僻地抢よび無歯科医地区住人の歯 科医療の確保と歯科衛生思想の啓発を図ることを目的と した歯科巡回診療が昭和 36 年より行われている1。この 巡回診療は, 厚生省, 沖縄県, 当該地方自治体㧍よび 8
(歯科) 大学すなわち東京歯科大学, 東京医科歯科大学, 日本大学歯学部, 日本歯科大学, 大阪大学歯学部, 大阪 歯科大学, 愛知学院大学茵学部, 九州菌科大学の協力の 下に実施されている。平成 10 年度は波照間島, 小浜島, 石坦島, 渡名喜村, 座間味村, 渡嘉敷村の 6 力所におい て歯科巡回診療が行われた2)。歯科巡回診療は, 保存, 補 
綴，口腔外科的な診療を行うのみならず，乳幼児揖よび その母親, 児童・生徒さらに高齢者に対して口腔衛生教 育の機会を提供する。今回われわれは, 平成 10 年 7 月 1 日上り 7 月 30 日にかけて渡嘉敷島 (島尻郡渡嘉敷村，人 口 689 名）に扮いて実施された，平成 10 年度第 2 回（通 算 155 回）歯科巡回診療に参加し，村民に歯科治療を行 うと同時に, 口腔衛生状態, 義歯装着者の咀嚼能力等に ついて調査を行ったので，それらの結果をここに報告す る。

\section{II．渡嘉敷村の概要 ${ }^{2)}$}

渡嘉敷村は沖縄県那覇市の西方 $32.1 \mathrm{~km}$ に位置し, 長 さ $9 \mathrm{~km}$, 幅 $2 \mathrm{~km}$, 面積 $15.64 \mathrm{~km}^{2}$ の渡嘉敷島を中心に大 小 10 余りの島より構成されている。島の大半は山岳地带 で中央の低地以外は山の急斜面や絶壁が海に迫り，海岸 は岩礁が多く所々に狭い砂浜が散見される。主な産業は 観光産業と漁業であり，特に前者はマリンレジャーを中 心として近年ますます拡大の傾向にあり，村の経済発展 の一翼を担っている。農業も行われているが，ほとんど 自己消費に充てられている。薬局，書店，衣料品店はな く，金融機関は渡嘉敷郵便局のみである。人口は 691 名， 世带数 311 户 (平成 10 年 4 月 1 日現在) で，年齢構成は 表 1 に示すごとくである。離島にしては珍しく 30 代から 40 代の構成人口が多いが, これは渡嘉敷島が観光地化さ れ，この年代が観光産業に従事していることによる。60 歳以上は $35.7 \%$ を占める。高齢者が多いのは離島の全般
的な傾向であろう。小学校は 2 校(渡嘉敷小学校：29 名, 阿波連小学校： 16 名)，中学校は 1 校 (渡嘉敷中学校： 25 名）で，高校からは本島の教育機関に進学する。乳幼児 は 61 名いるが, 乳幼児の保育施設として, 渡嘉敷へき地 保育所がある。

\section{III. 診療班の構成および設備}

診療班は，指導教授 1 名，歯科医師 3 名，歯科衛生士 4 名, 歯科技工士 2 名で,このうち沖縄県より歯科衛生士 2 名，歯科技工士 2 名が派遣された(図 1 )。歯科医師は 従来, 口腔外科, 保存科, 補綴科の 3 科より 1 名ずつの 3 人より構成されたが, 今回は保存科から 2 名, 高齢者 歯科から 1 名が参加した。歯科巡回診療が始まった時期 においては，口腔内の環境がかなり悪く抜歯を余儀なく されるケースが多数あったため，口腔外科医の参加が望 まれた。しかし，毎年行われる歯科巡回診療班の地道な 努力により，近年抜歯に至るケースは少数となった。逆 に,歯の保存に力点を置いた診療の要望が高まっている。 今回，その要望を反映して保存科から 2 名が参加した。 また, 高齢者においては, 義歯の製作, 調整の要望は依 然として強い。補経の専門的知識と技術を持つ歯科医が 今後とも必要であると思われる。

歯科巡回診療期間は平成 10 年 7 月 1 日より 7 月 30 日 までで，赴任，移動，打ち合わせ，報告会などを除いた 実質診療日数は 20 日であった。なお，同年 8 月 10 日よ ク 8 月 14 日の期間, 補綴医により, 義歯の調整を主とし

表 1 渡嘉敷村民の年齢構成

\begin{tabular}{c|c|c|c|c|c|c|c|c|c|c|c}
\hline \hline 年齢 & $0 \sim 9$ & $10 \sim 19$ & $20 \sim 29$ & $30 \sim 39$ & $40 \sim 49$ & $50 \sim 59$ & $60 \sim 69$ & $70 \sim 79$ & $80 \sim 89$ & $90 \sim$ & 計 \\
\hline 人数 & 88 & 43 & 52 & 104 & 108 & 49 & 88 & 98 & 48 & 13 & 691 \\
\hline
\end{tabular}

30 代から 40 代の村民が比較的多い。観光業等の産業があり仕事に従事できる環境が整っていることを示している。

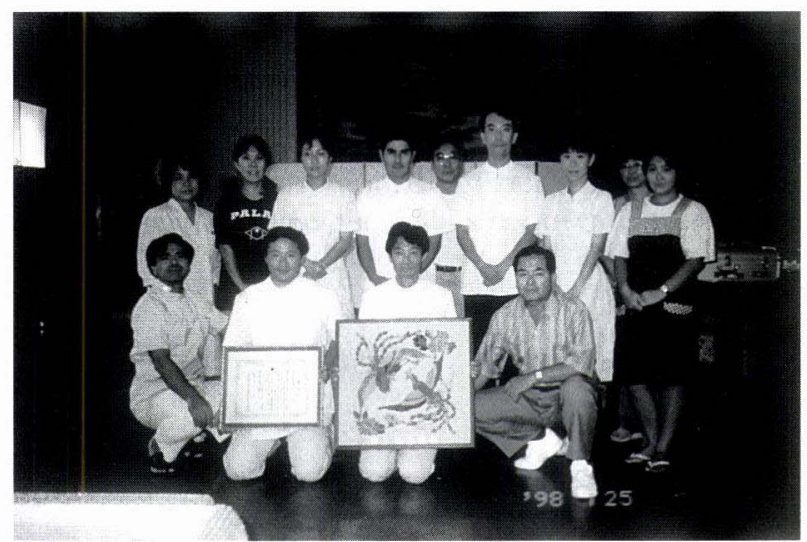

図 1 今回の㐘科巡回診療の参加者。前列右端は座間味昌茂 前渡嘉敷村村長 
た再診療が行われた。

現地においては公民館に歯科診療施設を設営した。設 営の状況については田中らの報告に詳しい3)。沖縄県福 祉保健部健康增進課所有の移動可能な歯科ユニット，コ ンプレッサー, 歯科用 X 線撮影装置のほか, 歯科材料が 準備され，一般的な保存，補経および口腔外科的処置を 行うのに不自由はなかった。一角には㐘科技工コーナー が設営され，中央においては高圧蒸気滅菌器が設置され た。谷田部らの報告4 にあるように，歯科薬品，材料は多 数あるが，類似の物品が重なっており整理する必要があ るものと思われる。

\section{IV. 診療 結 果 ${ }^{5}$}

\section{1. 受診者数}

初日に一般および乳幼児の検診を行い，翌日から一般 診療を開始した。診療受診者は，児童・生徒では 5 月の 検診結果の要治療者を中心に 38 名で, これは渡嘉敷村児 童・生徒の半分を越える。一般および乳幼児では, 巡回 診療班の検診結果からの治療希望者を中心に 132 名で, 児童・生徒を除いた全島民のほぼ2 割であった。これら に併せて診療期間中においても，随時検診および急患処 置を行った。今回の受診者数は前回とほぼ同様であり， これは㐘科巡回診療がこの島にしっかりと定着している ことを示しているものと思われる。

\section{2. 乳幼児および児童・生徒のう蝕眻患傾向}

乳幼児の口腔内状態は，かなり個人差があり，良好な 口腔内状態の乳幼児がいる一方で，多数のう蝕を有する 乳幼児も少なからず存在した。多数のう蝕を有する乳幼 児に一般的にいえることは, 診療行為に非協力的であり， う蝕の処置のみならず，歯ブラシ指導，フッ素塗布にも 抵抗を示した。これらの乳幼児は，せんべいといった硬 いものの捸食を忌避する傾向にあり，咀嚼能力抢よび全
身の発育といった観点からも問題が多い。このような多 数歯のう蝕を予防するためには，歯科医のみならず家庭 における口腔衛生管理および甘味攝取管理が特に重要で あると思われる。一方，保育園・幼稚園に抄いて寝か世 みがきを徽底して行っており，う蝕のほとんど存在しな かった乳幼児が相当数認められたのは，保母等の貢献に よるところが大きい。

琉球大学口腔外科の㐘科医師により平成 10 年 5 月に 行われた歯科検診の結果基に，う蝕賥患者率および DMFT を計算し，全国平均(平成 5 年度歯科疾患実態調 查報告）と比較した結果を困 2 に示寸。 7 歳，8歳にお いてう蝕䍜患者率は全国平均と比較して高い傾向にあ ク，DMFT も特に 6 歳に扔いて高い傾向にあった。渡嘉 敷島をはじめとする離島においてう蝕罹患者が多い傾向

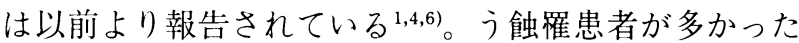
主たる原因については，谷田部らが言及しているよう に ${ }^{4)}$, 而親共働きの家庭が多いため, 間食の管理が十分に されていないことによると思われる。また，近年肥満型 の児童・生徒が増加の傾向にあるとのことからも，食生 活習慣の改善が重要と思われる。

\section{3. 成人および高齢者の口腔状態}

成人においてはう蝕が高度に進行した症例も多数晾療 した。これは，毎日の口腔内のケアが不十分であること とともに，㐘科診療が 1 年のうち 1 力月間しか行われて いないことによるものと思われる。しかし，そのように 高度に進行したう蝕を有する㐘において，通常なら抜髄 処置が適当と診断される状況においても，歯髄の生活力 は十分に強く，直接覆髄処置を施すことにより菌髄を保 存できた症例がかなりの数に上った。ストレスの多い都 会とは異なり，自然のなかで生活することで生体防御能 も自ずと高まっているのではないかと思われる。また， 漁業など重労働に従事している人が多く，咬耗が著しい
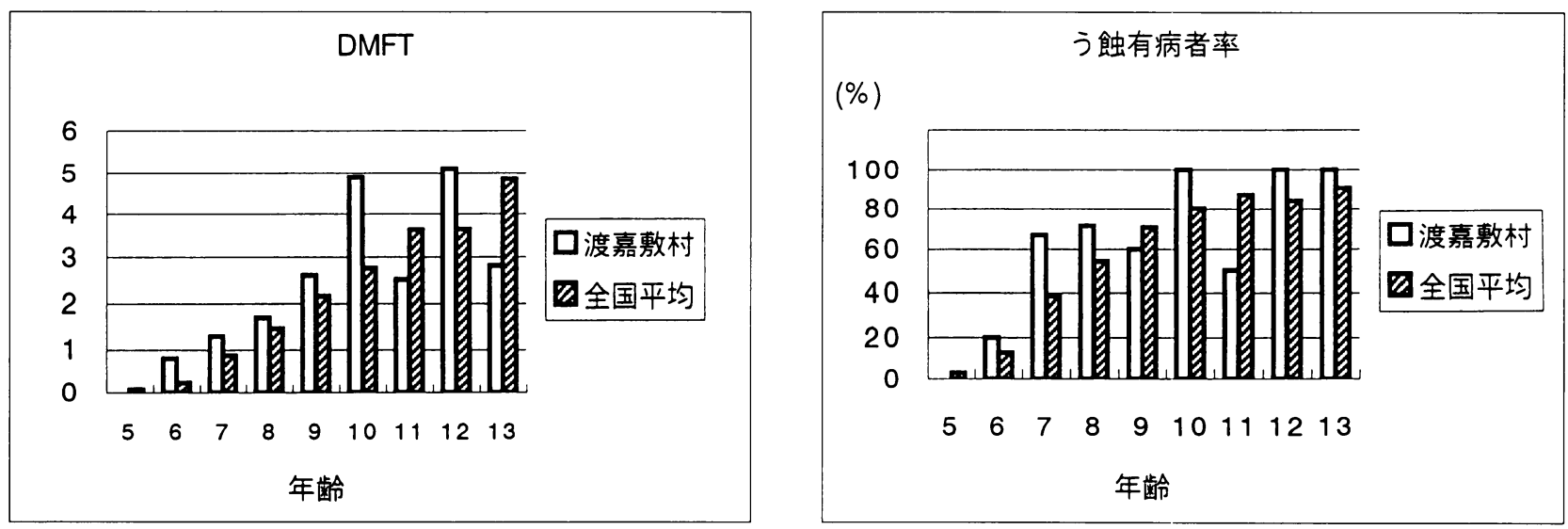

図 2 児童·生徒の DMFT およびう蝕有病者率。両者とも渡嘉敷村では全国平均 (平成 5 年度歯科疾患実態調查報告)を上回っ ている。 
症例が多数あった。歯周疾患が高度に進行している患者 も多数存在した。一般的に成人の口腔衛生状態は劣悪な 状態であり，多量のプラーク，歯石の沈着が認められる 症例も少なからず存在した。歯周疾患の子防には,プラー クコントロールとスケーリング，ルートプレーニングが 必要不可欠であるが，1 力月という限られた期間内に㧈 ける治療には限界がある。通年にわたる口腔内のメイン テナンスを四れる方法を模索すべきであろう。

高齢者においても相当数の残存歯を保有していたが, 義菌装着者, 特に老齿者における残存歯保護の意識は低 いように思われた。また，義歯に多量の denture plaque が付着している義歯装着者も多くみられ，義歯専用ブラ シを用いた義歯の清掃を指導していく必要があると考え られた。

\section{4. 診療内容}

歯科巡回診療は，1つの大学が 3 年間 1 力所の村ある いは島を担当する。今回，東京医科歯科大学が渡嘉敷村 を 3 年間担当した。この 3 年間の診療状況を表 2 に示す。 今回の診療班の特徵として, 除石, 永久歯の拔歯, 義歯 の製作および調整，フッ素塗布，TBI が過去 2 回に比べ 多かったことが挙げられる。以下にそれぞれの診療項目 について考察を加える。

\section{1) 保存処置}

レジン修復を中心にう蝕の治療を行った。今回，未就 学児，児童・生徒における保存処置は少数で，成人のう 蝕に対して行われたものが多い。これは，前回参加した 小児歯科医の精力的な治療によるものと思われる。

歯周疾患において, 重度の辺縁性歯周炎と診断され, 抜歯を余儀なくされた症例が多数に上った。歯周疾患を 予防および治療するためには，口腔内の良好な衛生状態 の獲得・維持が肝要であり，そのためには口腔衛生指導 および歯石除去といった原因除去のための治療が継続的 に行われる必要がある。今回，可及的に時間を割き口腔 衛生および保健指導を行うとともに, 歯石除去を行った。 しかし， 1 年に 1 回，1力月間のみの診療では限界があ る。将来的には，島内に歯科医師の常駐が理想だが，そ の前段階として歯周疾患の予防，およびプライマリーケ アを行う設備, 人員（㐘科衛生士）を島内に確保し，継 続的な検診，指導，および除石等の処置を行うことが望 まれる。

\section{2 ) 外科処置}

永久歯の抜歯が今回多かったのは，辺縁性㐘周疾患の 進行による抜歯症例が多数に上ったことによる。保存不 可能と診断された歯を中心に抜歯を行ったが，通常の歯

表 2 処置結果

\begin{tabular}{|c|c|c|c|c|c|c|c|c|}
\hline 保存処置 & 断䯣 & 抜髄 & 感根治 & インレー充填 & レジン充填 & 歯石除去 & その他 & 小計 \\
\hline $\mathrm{H} 8$ & 1 & 13 & 22 & 5 & 145 & 126 & 133 & 445 \\
\hline $\mathrm{H} 9$ & 11 & 12 & 24 & 19 & 369 & 95 & 506 & 1,036 \\
\hline H 10 & 2 & 11 & 33 & 11 & 243 & 200 & 303 & 803 \\
\hline 外科処置 & 抜歯 (乳歯) & 抜歯 (永久歯) & & & & & その他 & 小計 \\
\hline H 8 & 13 & 36 & & & & & 33 & 82 \\
\hline $\mathrm{H} 9$ & 31 & 9 & & & & & 11 & 51 \\
\hline H 10 & 1 & 59 & & & & & 29 & 89 \\
\hline 補綴処置 & クラウン & 架工義歯 & 有床義歯 & リベース & 修理 & 印象·咬合採得 & 調整, その他 & 小計 \\
\hline H 8 & 16 & 0 & 15 & 23 & 20 & 77 & 85 & 236 \\
\hline H 9 & 18 & 1 & 8 & 27 & 31 & 69 & 58 & 212 \\
\hline H 10 & 14 & 4 & 16 & 11 & 31 & 108 & 113 & 297 \\
\hline その他 & フッ素䤰布, TBI & & & & & & その他 & 小計 \\
\hline H 8 & 22 & & & & & & 150 & 172 \\
\hline H 9 & 35 & & & & & & 95 & 130 \\
\hline H 10 & 45 & & & & & & 136 & 181 \\
\hline 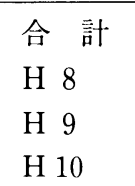 & & & & & & & & $\begin{array}{r}935 \\
1,429 \\
1,370\end{array}$ \\
\hline
\end{tabular}

処置項目のなかではレジン充填が最も頻度が高かった。抜歯のほとんどは歯周疾患に起因するものであった。有床義歯 の製作数および修理数は 1 力月という期間と技工能力から今回の症例数が限界であろう。 
周治療を行えばあるいは保存可能であったかもしれない 歯も一部抜歯した。これは，巡回診療の 1 力月の間に義 歯装着まで終了させる必要があり，歯周疾患処置を含む 前処置を早期に終了させなくてはならないという制約に よるものであった。このことは今後検討が必要と思われ た。う蝕が高度に進行して，抜歯に至った症例は少数で あった。智歯の抜歯も何例かあったが，難抜㐘にいたる 症例はなかった。

3 ）補緅処置

㐘科巡回診療は 3 年間同一地区を同じ大学が担当す る。したがって，今回をもって東京医科歯科大学の渡嘉 敷村診療は終了となるため，われわれとしては東京医科 歯科大学の責任として，今後義歯製作および修理を希望 する患者を最小限に抑えるべく，補緅を専門とする歯科 医を中心に精力的に義歯製作，および修理を行った。そ の結果が, 有床義歯製作, 修理, 調整数の増加につながっ たものと思われた。1つの義歯の使用年数は平均 12 年く らい(谷田部ら) ${ }^{4)}$ であり，人工歯の咬合面が中等度から 高度に咬耗している義歯も多かった。顎堤が高度に吸収 している難症例も十数例あった。これは, 高㱓者が多い ことにも起因するが, 義歯の調整が容易に行えないため, 適合不良の義歯を長年にわたり使用してきたことも一因 であると思われた。

4 ）口腔衛生および保健指導，フッ素塗布

乳幼児に対するフッ素塗布は，保育園にて口腔衛生指 導を行った後，希望者全員に行った。また，公民館にお ける診療室においても随時希望者に行った。辺縁性歯周 疾患罹患者に対しては，可及的に時間を割き TBI を行っ た。しかし，口腔内の衛生管理に対する意識は低い傾向 にあり，今後改善を図る必要があると思われた。また，

フッ素塗布に比較して，フッ素洗口はより経済的である とともに家庭において行うことの可能なう蝕子防法であ る。歯科医師，歯科衛生士の常駐していない渡嘉敷島に おいては非常に有効であると思われる。

\section{V. 口腔衛生および保健指導 ${ }^{5)}$}

歯科衛生思想の啓発を図ることを目的とした口腔衛生 および保健指導は以下の 5 つのグループを対象に延べ 7 回行われた。

\section{1. 保育所，幼稚園における歯磨き指道}

保育所，幼稚園における衛生教育は，染め出し液によ る歯垢染色と歯ブラシ指導をすべての園児を対象として 行ったが，保育所㧍よび幼稚園の先生の歯科衛生教育が 行き届いており，歯垢染色および歯ブラシ指導を忌避す る園児はほとんどいなかった。そのため，全般的に園児 の口腔内の衛生状態は良好であった。しかし，一部の園 児は衛生指導に抵抗を示し, これらの園児の口腔衛生状
態は劣悪であった。このような園児に関しては，本人の みならず母親および家庭全体に対する口腔衛生および保 健指導が必要と思われた。

\section{2. 母親歯科衛生教育}

児童・生徒の母親を対象に口腔衛生指導を行った。先 に示したごとく小学生は全般的にう蝕羅患傾向が全国平 均より高い傾向にある。常時清涼敛料水および菓子を搨 取していることがその原因の一つとして考えられる。し たがって，母親に扔やつの意義打よび护やつの与え方に 関する正しい知識を得てもらい，おやつを適切に子供に 与えることができるようになることで，う蝕発症はかな り予防できるはずである。そこで今回，おやつの与え方，選 び方を中心に，虫歯を予防するにはどうしたらよいかを スライドにてわかりやすく示した。また,フッ素塗布につ いて、拉よびキシリトールについてもコメントを加えた。

\section{3. 小学生対象の口腔衛生および保健指導}

小学生対象の口腔衛生㧍よび保健指導は，う蝕の各段 階（CO-C 4）を有する抜去歯牙を実際に見せ，う蝕につ いて説明したところ，実際のう歯を目の当たりにしてう 蝕の怖さを実感したようであった。さらに，咀嚼に関し て講義を行い，全身の成長における咀嚼の重要性につい て説明した。近年渡嘉敷村においても肥満児が増加の傾 向にあるとのことであり，咀嚼をおろそかにすることに より肥満につながる危険性についても演繹した。また， 実際の咀嚼能力について睡嚼の進行に伴い色が変わる色 がわりガムを用いた実習を行った（後述）。

\section{4. 中学生対象の口腔衛生および保健指導}

中学生には RD テスト「昭和」(昭和薬品, 東京), サ リバスター潜血用（昭和薬品，東京）を実際に行っても らった。RD テストは簡便な口腥内の衛生状態を判定す るテストで，唾液中の S. mutans などのう蝕原性細菌数 の多少を反映する。また，サリバス夕一潜血用は，唾液 中の潜血濃度を測定するもので, 歯周疾患のスクリー二 ングとして利用されている。以上の 2 つのテストを実習 として行うとともに，それぞれのテストに関連づけなが ら，う蝕，および歯周疾患についてわかりやすく説明し た。 RD テスト，サリバテストとも特に劣悪な結果を示し た生徒はいなかったが，実際に実習に参加したことで， 自分たちの口腔内の衛生状態について, 関心が高まった ようであった。

\section{5. 高齢者に対する口腔衛生および保健指導}

高齢者に対して，義歯の手入れ，口腔内清掃について 講義を行った。また，特に誤䠢性肺炎についても注意を 促した。䛊嚥性肺炎は, 嚥下機能が衰えている高齢者に 多く発症する肺炎7)で，誤喂により食物等が気管支に入 り込むことにより起こる。口腔内が不潔になっていると 特に発症しやすく，その予防には，誤嚥を減らす訓練と 
ともに，口腔内環境の改善が重要とされている。今回， 䛊嚥性肺炎を予防するうえでも，義歯の手入れ，口腔内 清掃がいかに重要であるかを説明し，理解してもらった。

\section{VI. ガムを用いた咀哷能力判定および義歯装着者の食品 摄取状況に関するアンケート調査}

咀嚼の進行に伴い色が変わる色がわりガムを用いて, 児童・生徒の咀嚼能力を測定した。色がわりガムは, 赤 と白のガムを 30 秒間に 40 回咀嚼してもらい, その時点 におけるガムの色から 5 点満点で咀嚼能力を判定するも のである ${ }^{8)}$ 。その結果, $6 \sim 9$ 歳児(15 名)の平均は 2.4 , $10 \sim 12$ 歳児 (16 名) の平均は 2.34, 13〜 15 歳児 (19 名) の平均は 2.79 と成長とともに咀嚼能力の上昇が認めら れた。平均よりかけ離れて咀嚼能力の悪い児童はいな かった（㘡 3 ）。

また，義歯装着者（26 名）に対し食品攝取状況に関す るアンケート調查を行った。このアンケート調查は, 全 部床義歯装着者の咀嚼能力を客観的かつ簡便に評価する 一つの方法として, 東京医科歯科大学歯学部高齢者歯科 学講座の内田ら ${ }^{9)}$ が考案したものである。表 3 に示す 20 品目の食品について，普通に食べられると回答した食品 の割合をパーセンタイル值として算出し，その值を掑取 可能率とした。その結果，アンケートの協力を得た渡嘉 敷村義歯装着者のうち, 上下顎総義歯装着者の平均は 55.83 点, 総義歯 + 部分床義歯装着者の平均は 71.88 点, 上下顎部分床義歯装着者の平均は 82.5 点, 天然歯十総義 歯または部分休義㐘装着者の平均は 85 点であった（表 4 ）。患者が義歯に満足している場合，上下顎総義歯装着 者で 60 点以上, 上下顎部分床義歯装着者で 80 点以上を 示す。今回の結果から，渡嘉敷村の高㱓義歯装着者の大 部分はおおよそ良好に咀嚼していると思われた。ただし 今回義歯に関する治療を行った患者のなかには，顎堤の 吸収が著しく義歯の安定を得ることが困難な症例や，適 合不良な義歯を常用している症例が多数認められたこと から，各人が咀嚼可能なように調理を工夫していること も考えられた。また，上下顎総義歯装着者の平均は 60 点 を下回っていたことからも，専門的技術を有する補緅専 門医による治療が望まれる。

\section{VII. 歯科巡回診療システムの展望}

現在の歯科巡回診療システムは 3 年間同一大学が同一 簓所を担当するが，毎回異なったテーマを主眼としてい る。3 年間同一簓所を担当するというメリットを生かし， 統一テーマの下に活動することで，より多くの情報が得 られるものと期待される。また，補緅医による再診療シ ステムにおいて通常の歯科ユニットの設営はされない が, 再診療をスムーズに行うにあたり, 通常の歯科ユニッ
トの設営を含めた最低限の環境は整える必要があろう。 巡回診療を行っている地域において，確かに抜歯を余儀 なくされるケースは減少の傾向にあるが，依然としてロ 腔内の環境が劣悪であるケースも多かった。歯科衛生士 等の常駐を念頭に置いた，日常的な予防活動および歯科

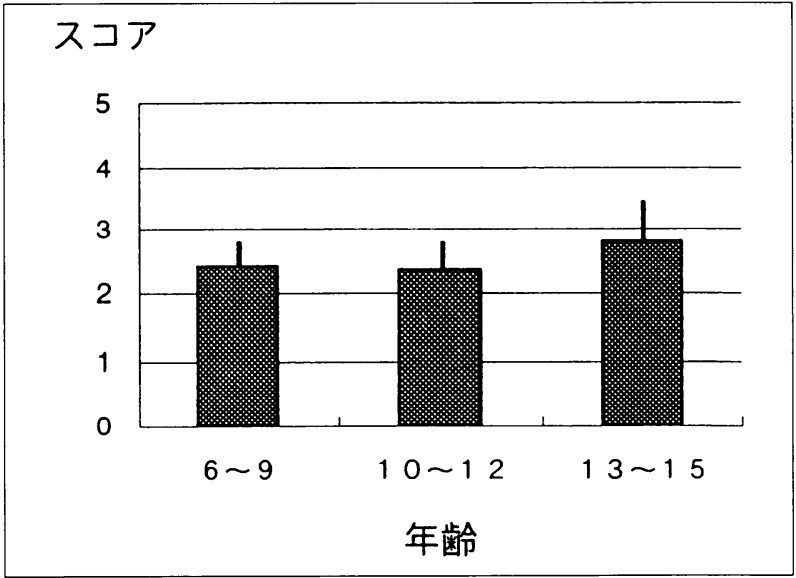

図 3 色がわりガムのスコア。年需が高くなるに従いスコア の上昇が認められた。

表 3 義歯装着者の食品捸取状況に関す るアンケートの食品一覧9)

\begin{tabular}{|c|c|}
\hline 食品名 & 咀嚼難易度 \\
\hline ごはん & 4 \\
\hline ほうれん草（ゆで） & 9 \\
\hline ドーナッツ & 16 \\
\hline 枝豆 & 18 \\
\hline 八ム & 18 \\
\hline 油あげ & 23 \\
\hline かまぼこ & 26 \\
\hline 甘栗 & 32 \\
\hline キャベツ（生） & 36 \\
\hline あげせんべい & 41 \\
\hline 鳥からあげ & 42 \\
\hline なす（漬け物） & 45 \\
\hline とんかつ & 57 \\
\hline ピーナッツ & 61 \\
\hline おこし & 62 \\
\hline イ力（焼き） & 74 \\
\hline たくあん & 75 \\
\hline 酢だこ & 78 \\
\hline あわび（生） & 89 \\
\hline するめ & 96 \\
\hline
\end{tabular}

これらの食品のうち普通に食べられると 回答された食品の割合を㴻取可能率とし た。 
表 4 義歯装着者の食品摂取状況に関するアンケート結果

\begin{tabular}{|c|c|c|c|c|c|c|}
\hline 性別 & 年齢 & 上顎義歯 & 下顎義歯 & 残存歯数 & 攝取可能率 & 摂取可能率の平均 \\
\hline \multicolumn{7}{|c|}{$\langle$ 〈下総義歯〉 } \\
\hline $\mathrm{f}$ & 71 & $\mathrm{FD}$ & FD & 0 & 100 & \\
\hline $\mathrm{f}$ & 73 & $\mathrm{FD}$ & FD & 0 & 35 & \\
\hline $\mathrm{f}$ & 76 & FD & FD & 0 & 65 & \\
\hline $\mathrm{f}$ & 77 & $\mathrm{FD}$ & FD & 0 & 40 & \\
\hline $\mathrm{m}$ & 81 & $\mathrm{FD}$ & $\mathrm{FD}$ & 0 & 95 & \\
\hline $\mathrm{m}$ & 84 & FD & $\mathrm{FD}$ & 0 & 0 & 55.83 \\
\hline
\end{tabular}

〈総義歯十部分床義歯〉

\begin{tabular}{|c|c|c|c|c|c|}
\hline $\mathrm{f}$ & 67 & FD & PD & 3 & 65 \\
\hline $\mathrm{f}$ & 69 & FD & PD & 3 & 80 \\
\hline $\mathrm{m}$ & 68 & PD & $\mathrm{FD}$ & 10 & 75 \\
\hline f & 71 & FD & $\mathrm{PD}$ & 3 & 60 \\
\hline $\mathrm{m}$ & 73 & FD & PD & 1 & 65 \\
\hline $\mathrm{f}$ & 74 & $\mathrm{PD}$ & FD & 2 & 85 \\
\hline $\mathrm{m}$ & 75 & $\mathrm{FD}$ & $\mathrm{PD}$ & 5 & 65 \\
\hline $\mathrm{m}$ & 77 & $\mathrm{FD}$ & $\mathrm{PD}$ & 8 & 80 \\
\hline
\end{tabular}

〈上下部分床義歯〉

$\begin{array}{ccccrrr}\mathrm{f} & 60 & \mathrm{PD} & \mathrm{PD} & 10 & 35 & \\ \mathrm{f} & 64 & \mathrm{PD} & \mathrm{PD} & 14 & 95 & \\ \mathrm{~m} & 67 & \mathrm{PD} & \mathrm{PD} & 13 & 75 & \\ \mathrm{f} & 70 & \mathrm{PD} & \mathrm{PD} & 13 & 100 & \\ \mathrm{~m} & 76 & \mathrm{PD} & \mathrm{PD} & 12 & 95 & \\ \mathrm{~m} & 80 & \mathrm{PD} & \mathrm{PD} & 18 & 95 & 82.50\end{array}$

〈天然歯十総義歯または部分床義歯〉

$\begin{array}{llllll}\mathrm{f} & 70 & \mathrm{~N} & \mathrm{PD} & 14 & 90\end{array}$

$\begin{array}{llllll}\mathrm{f} & 80 & \mathrm{~N} & \mathrm{PD} & 15 & 85\end{array}$

$\begin{array}{llllll}\mathrm{f} & 70 & \text { FD } & \mathrm{N} & 9 & 80\end{array}$

残存歯が増すに従い，攝取可能率も増加する傾向があった。義歯装着者でも攝取可能な食 品の割合が比較的高いことが明らかとなった (f：女性, $\mathrm{m}$ ：男性, $\mathrm{FD}$ : 総義歯, $\mathrm{PD}$ ： 部分床義歯, $\mathrm{N}$ ：天然歯）。

診療を検討する必要があろう。

\section{VIII. ま と め}

今回われわれは，平成 10 年 7 月 1 日より 7 月 30 日に かけて渡嘉敷島（沖縄県島尻郡渡嘉敷村，人口 689 名） において実施された，平成 10 年度第 2 回（通算 155 回） 歯科巡回診療に参加し，以下のような知見を得た。

1. 児童・生徒のう蝕有病者率は全国平均と比較して 高い傾向にあり，甘味飲料を頻回に掑取していると いった悪い食習慣が主な原因と考えられた。

2. 処置内容で最も多かったのはレジン修復であった が, 渡嘉敷村には高龄者が多く, 義歯の製作および 修理も多数行った。また, 高度に進行した歯周疾患 に罹患した成人も多数認められた。

3. 児童・生徒, 母親, 高齢者に対して口腔衛生およ
び保健指導を行い，おおむね好評を博した。特に児 童·生徒において， 口腔内の衛生管理についてのモ チベーションのために, RD テスト,サリバテストを 導入した実習は有効であった。

4. 義歯装着者はおおむね現在の義歯に満足している ようであった。

5. 歯科巡回診療に関して，1 カ月という短期間の診 療のみでは対処できない問題が多数あり，日常的な 予防活動挹よび歯科診療との関連において，今後巡 回診療の在り方について検討する必要があると思わ れた。

\section{謝辞}

稿を終了するにあたり，今回の㐘科巡回診埃に御協力をい ただきました金城マサ子氏 (沖縄県福祉保健部)，稲福恭雄氏 
(沖縄県福祉保健部健康増進課)，久田友弘氏(同)，平良 昭 氏(同)，国仲匡氏(同)，嘉陽宗成氏(同)，下地 仁氏(同)， 宮城重子氏(同)，宮良千栄子氏(同)，渡嘉敷村役場，南部保 健所, 渡嘉敷小中学校, 阿波連小学校, 渡嘉敷幼稚園, 渡嘉敷 へき地保育所ならびに関係者各位に心から謝意を表します。 また，お世話になりました渡嘉敷村民の方々にも深謝いたし ます。

最後に，今回の㐘科巡回診療班に御支援をいただきました 大山喬史 東京医科歯科大学歯学部附属病院長に感謝いたし ます。

\section{文献}

1）米満正美，岡田昭五郎：沖縄県における離島歯科巡回診 療を顧みて。歯界展望 55：301-311，1980。

2) 沖縄県福祉保健部健康增進課：第二回歯科巡回㟝療才リ エンテーション資料 (渡嘉敷村)。

3）田中信幸, 稲井紀通, 馬場一美, 内田和子, 須田英明：沖
縄離島診療記。口病誌 $62(2) ： 133-138,1995$.

4）谷田部優，石川雅章，島田康史，溝口玲子，野島たかね, 長尾正憲：沖縄県渡嘉敷島住民の口腔衛生状態につい て。口病誌 $65(2) ： 42-47,1998$.

5）沖縄県福祉保健部健康增進課：平成 10 年度第二回（通算 155 回）歯科巡回診療実施実績報告書。

6）八幡三郎, 佐藤 誠, 佐々木三男：沖縄県西表島西部地区 住民の口腔衛生状態について. 口病誌 $48(2) ： 230$ - 239, 1981.

7）米山武義：口腔ケアの今日的とらえ方と䛊嚥性肺炎予 防。歯界展望 91：1276-1279，1998。

8) Ono, Y., Saito, M., Iijima, H., Miwa, Z., Teng, N., Tanaka, M., Takagi, Y., Seki, T. and Suzuki, Y. : A Study on Masticatory Efficiency in Children by New Chewing-gum Part 1. Fabrication of New Chewinggum. Proceedings of the First Conference of Pediatric Dentistry Association of Asia (Abstract) : 144-145, 1997.

9）内田達郎，長尾正畫：全部床義歯装着者の簡便な咀嚼能 力評価法. Dental Diamond 18 (13) : 22-25, 1993 